\title{
Market Effect of Listed Corporate Social Responsibility Report Disclosure-Based on Combined Test of the Double Events
}

\author{
Zhenyu Ji \\ School of Management, Jinan University, Guangzhou, China \\ Email: jzycc123@163.com
}

Received 21 March 2015; accepted 10 April 2015; published 14 April 2015

Copyright (C) 2015 by author and Scientific Research Publishing Inc.

This work is licensed under the Creative Commons Attribution International License (CC BY). http://creativecommons.org/licenses/by/4.0/

(c) (i) 0 pen Access

\begin{abstract}
CCTV Financial 50 Index $^{1}$, the first stock index released by China's state media, was launched on June 6, 2012. As one of the elements looked at by the index to selected 50 best performance listed companies, social responsibility becomes a hot spot of social attention. This paper investigates the market effect of listed companies in A-share market which disclosed social responsibility report in 2010. Results of the study show that the information in Corporate Social Responsibility (CSR) Report has no significant market effect as the disclosure of CSR Report. However, when the White Book of Chinese CSR Report is released, the information in CSR Report generates significant market effect. Moreover, the higher the quality of CSR Report disclosed, the more significant the market effect. In conclusion, the White Book of Chinese CSR Report has a reinforcing action on the information in CSR Report.
\end{abstract}

Keywords

Corporate Social Responsibility Report, White Book of Chinese CSR Report, Market Effect

\section{Introduction}

On June 6, 2012, China's first media index-“CCTV Financial 50 Index” was official released, and Corporate Social Responsibility (CSR) as an important dimension of the selection for the index. With the society's atten-

${ }^{1}$ CCTV Finance 50 Index was released by CCTV financial channel and the Shenzhen securities information co., Limited. The Index was selected by CCTV financial channel, Peking University, Fudan University, Renmin University of China, Nankai University, Central University of Finance and Economics, as well as the Chinese Institute of Certified Public Accountants, Dagong Global Credit Rating Co., Limited and other professional institutions. CCTV Finance 50 Index was measured from such five dimensions as Growth, Innovation, Return, Corporate governance, Social responsibility, and each dimension to choose 10, total 50 A-shares Corporate constitute the sampled stock.

How to cite this paper: Ji, Z.Y. (2015) Market Effect of Listed Corporate Social Responsibility Report Disclosure-Based on Combined Test of the Double Events. Open Journal of Business and Management, 3, 163-176.

http://dx.doi.org/10.4236/ojbm.2015.32016 
tion to corporate social responsibility, the disclosure of CSR Report not only meets the needs of society of the social responsibility information, but also could respond to the requirements of the government actively. In 2006 , the Corporate Law specifically requested that enterprise should undertake social responsibility; The Listed Company Social Responsibility Guidelines was issued by the Shenzhen Stock Exchange on Sept. 18, 1968 clearly put forward the listed companies should take responsibility for social stakeholders of all parties concerned; The Guidelines for Central Enterprises to Fulfill Social Responsibility issued by the SASAC on Jan. 4, 2008 clearly put forward the general requirements of fulfillment of social responsibility for central enterprises; In 2008, the Shanghai Stock Exchange issued the CSR Report Guidance and Review Working Paper, making the detailed requirements of report preparation of corporate social responsibility. The CSRC definitely required more than 360 listed companies of the Shenzhen Stock Exchange and the Shanghai Stock Exchange should disclose CSR Report.

According to the Social Responsibility Information Disclosure of Listed Companies in China Research Report 2011, up to June 30, 2011, all kinds of CSR Report released by Chinese A-share listed companies, a total of 531, compared with last year's 483, increased by $10 \%$, the disclosure of CSR Report presented a steadily fast development trend.

Based on signal transmission theory, corporation reflects the fulfillment of social responsibility by disclosing CSR Report to deliver positive signals to the market. The disclosure forms of Chinese CSR Report divide into mandatory disclosure and voluntary disclosure; some companies are required to disclose compulsorily and the quality of information disclosed by different companies are short of coincident standard, while some ones can disclose voluntarily.

At present, CSR Report as a carrier of the social responsibility information is generally disclosed with annual financial statements. Then, whether the market effect will be influenced by information overload or functional fixation? That is, for the companies which disclosed CSR Report, whether the market can react to each. Besides, whether the market can identify the quality of CSR Report ahead of the third-party rating reports related; whether the market effect become more significant while the quality of CSR Report become higher? All the abovementioned problems remain to be tested. This paper aims to test the market effect of companies in A-share market which disclosed CSR Report; moreover, though the combined test of the double events of CSR Report and White Book of Chinese CSR Report, this paper expects the results of this research can provide rational advice to normalize CSR Report.

\section{Literature Review and Research Hypothesis}

\subsection{Literature Review}

With more and more attentions were paid on corporate social responsibility, Ingram [1] used the market effect to test validity of the disclosure of CSR Report, and got a conclusion that the information in CSR Report generates significant market effect. Margolis and Walsh [2] found that corporate social responsibility was no related with corporate values. McWilliams and Siegel [3] found that there is no association between corporate social responsibility and financial performance. Waddock and Graves [4], Hillman and Keim [5], Verschoor and Murphy [6], Hull and Rothenberg [7] found corporate social responsibility could bring to positive financial performance. Anderson and Frankle [8], Ainscough, Shank, and Manullang [9], Cheung, Tan, Ahn, Zhang [10], Cheung et al. [11] discussed the influence of social responsibility on market effect and found corporate social responsibility brought positive market effect. Most of these research results show that corporate social responsibility has a positive impact on the corporate value.

Some China's scholars used corporate social responsibility accounting data to discuss the relationship between social responsibility and corporate value, Yu-Qing Chen, Li-Li Ma [12] found there was no strong correlation between corporate value and the social responsibility information though establishing the social responsibility of stakeholder contribution index system. Su-Bin Wen, Wan Fang [13] found that social responsibility performance had a negative impact on financial performance by building a stakeholders model. Moreover, there are studies by using content analysis to measure corporate social responsibility, Zheng Lee [14] adopted content analysis method to measure the social responsibility information and found the higher the quality of CSR Report disclosed, the lower of corporate value. Xian-Zhong Song, Ming-Xiao Gong [15] used content analysis method to measure the quality of corporate social responsibility information and found that social responsibility information's quality and decision value relevance had low correlation. Hong-Tao Shen, Yi Yang [16] used corporate 
social responsibility information disclosure index (SDI) to measure CSR information disclosure situation of Ashare companies of petrochemical plastics industry and found that social responsibility information disclosed has value relevance.

In the past, there were no uniform requirements in the disclosure of CSR Report, the measure methods of corporate social responsibility were not consistent, and so studies about the effects of corporate social responsibility to corporate value had no accordant conclusion. Along with the legislations of CSR Report were successively issued, the CSR rating agencies put more attention on CSR Report, so some scholars investigated the influence of CSR Report disclosed on corporate value. Song Zhu [17] used Rankins CSR Ratings (RKS) to study the fulfillment of social responsibility and found that disclosure of CSR Report affected the market's evaluation of earnings information quality. Yan-Jun Jiang et al. [18] found that the quality of CSR Report played a significant positive role in market effect. Hua-Yun Zhai [19] found that the investors paid lots attention to the quality of CSR Report disclosed, the higher the quality of corporate social responsibility information disclosed, the lower the price differences of stock exchange and the higher stock turnover ratio.

Through the literature review, we would find that there is no consistent conclusion of the study of between corporate social responsibility and corporate value; the main reason may be the measure methods of CSR Report social responsibility are different. The market will pay more attention to the disclosure of CSR Report with the emergence of social responsibility report disclosed by listed companies and the CSR rating agencies. Besides, most of the companies disclose CSR Report and Annual Financial Report at the same time, the possible problem of functional fixation and information overload in the market may lead to the information of CSR Report lacks of adequate attention of the market. In addition, the disclosure of CSR Report in China's listed companies is still in its infancy stage, lacking of specific standards and reliable third-party agencies.

\subsection{Research Hypothesis}

CSR Report is the information carrier of the fulfillment of social responsibility. Based on signal transmission theory, the disclosure of CSR Report can embody the positivity of the fulfillment of social responsibility and sustainable development capacity, it's benefit to improve social image and reputation because good social reputation can bring the long-term loyal customers, reduce the risk of punishment caused by lacking social responsibility, such as environmental pollution fines litigation (Hong-Tao Shen [20]). Besides, the fulfillment of social responsibility can get the government's support with environmental protection tax incentives and achieve bank borrowing with lower financing cost (Gross and Roberts [21]; Yi-Xiang Huang, Yuan-Hu Li [22]), also can improve corporate performance in the future.

In recent years, problems resulted from the lack of social responsibility in China's listed companies are very serious, especially for pharmaceutical industry. After the exposure of drug safety problems, lots of companies received negative assessment with falling sales. Along with the supervision of media and government, corporate social responsibility becomes the focus of the market. Moreover, as the important channel for information disclosure of social responsibility, CSR Report can bring positive effect on the companies. Based on above analysis, this paper puts forward assumption 1:

- Assumption 1: Social responsibility report of listed company can produce positive market effect when CSR Report is disclosed.

Some studies found the phenomenon of functional fixation in China's capital market were ubiquitous; investors always neglect useful financial information and non-financial information instead of focusing only on net income or net profit changes indicators, as a result, information in CSR Report has no significant market effect when the social responsibility report is disclosed by companies. In addition, information overload, caused by the simultaneity of the disclosure of the CSR Report and Annual Financial Report, makes the speed of information dissemination faster than receivers can assimilate information; it also impacts the market effect. Moreover, investors are lack of recognition of CSR Report; the information offered by third-party CSR rating agencies is few, hysteretic and short of authority, reliability; all of the above can lead to the disclosure of CSR Report has no significant market effect.

Since 2010, economic department of corporate social responsibility research center, Chinese Academy of Social Sciences publishes the White Book of Chinese CSR Report annually, through six index rating dimension to score the disclosure of CSR Report. On Dec. 17, 2011, the fourth China's corporate social responsibility summit for the White Book of Chinese CSR Report held in Beijing and officially issued the White Book of Chinese 
CSR Report 2011 compiled by economic department of corporate social responsibility research center; these gained media's attention and delivered authoritative reliable CSR rating information to the market, while the market makes a positive response to the CSR Report. Moreover, the market will pay attention to White Book of Chinese CSR Report rating information; the higher rating means the higher the quality of CSR Report disclosed, means more efficient the information dissemination, means more comprehensive the fulfillment of social responsibility, means more significant the market effect. Therefore, White Book of Chinese CSR Report could strengthen information; CSR Report can generate significant market effect while the White Book of Chinese CSR Report is disclosed. Based on above analysis, this paper puts forward assumption 2 and assumption 3:

- Assumption 2: CSR Report of listed company can generate significant market effect while the White Book of Chinese CSR Report is disclosed.

- Assumption 3: When White Book of Chinese CSR Report is disclosed, the higher the quality of CSR Report disclosed, the more significant the market effect.

\section{Research Samples and Study Design}

\subsection{Research Samples}

This paper selects listed companies in A-share market as research samples, eliminating ST companies and financial companies while rejecting the samples which have incomplete data; finally gets the sample includes 1857 observations, including the samples those disclosed CSR Report and Annual Financial Report simultaneously, for a total of 474; while the samples without CSR Report disclosure total 1383. All of these samples and data come from CSMAR and WIND.

\subsection{Variable Definition}

According to the event study windows selected, this paper adopts market-adjusted returns model to calculate Cumulative Abnormal Return (CAR) of samples on corresponding windows. In this paper, the CAR is defined as the Cumulative Abnormal Return of the time-interval which extends from trading day -10 to trading day +10 relative to the event-day, the definition of other major variables are shown in Table 1.

\subsection{Study Window and Research Method}

\subsubsection{SCR Report Disclosure Window}

CSR Report and Annual Financial Report are usually disclosed simultaneously, in order to eliminate the influence of the disclosure of Annual Financial Report; this paper will use Sample Matching Method and Revenue Model to test the market effect of the disclosure of CSR Report. This paper calculates CAR of the selected window, extending from 10 trading day before to 10 trading day after relative to the CSR Report disclosure day, respectively for the CSR Report disclosure samples and matching samples; and whether the companies which disclosed CSR Report can achieve market effect will be tested by matching samples mean T-test and matching sample median Z-test. The basic matching principles of Sample Matching Method in this paper are as follows:

1) Matching samples will be selected from the companies which did not disclose CSR Report in 2010;

2) Matching samples and research samples are belonged to the same industry, and the classification standards are according to the 13 categories of industry standards of CSRC;

3) The difference of Return on Asset between matching samples and research samples within 20\%, i.e. $|R O A C H R|<20 \%$;

Table 1. Major variables definition.

\begin{tabular}{|c|c|c|}
\hline Variable code & Variable explanation & Variable evaluation \\
\hline CAR & Cumulative abnormal return & Cumulative abnormal return of the event window $(-10,10)$ \\
\hline $\mathrm{UE}$ & Unexpected earning & $\begin{array}{l}\text { (Earnings per share } 2010 \text { - Earnings per share 2009)/ } \\
\text { Stock price of 1day before the event window } 2010\end{array}$ \\
\hline CSR & The disclosure of SCR Report & If the sample disclosed SCR Report, CSR $=1$; otherwise, CSR $=0$ \\
\hline EPS & Earnings per share & Earnings per share 2009/Stock price of 1day before the event window 2009 \\
\hline
\end{tabular}


4) The difference of Total Asset Size between matching samples and research samples within 7\%, i.e. $\mid$ AssetCHR $<20 \%$;

The calculated formulas of $|R O A C H R|$ and $\mid$ AssetCHR $\mid$ as follows:

$$
|R O A C H R|=\left|\frac{R O A_{i}-R O A_{s}}{R O A_{s}}\right| \quad \mid \text { AssetCHR }|=| \frac{\text { Asset }_{i}-\text { Asset }_{s}}{\text { Asset }_{s}} \mid
$$

Among the above:

$R O A_{i}=$ The Return on Asset of matching samples;

$R O A_{s}=$ The Return on Asset of research samples;

Asset $_{i}=$ The Total Asset Size of matching samples;

Asset $_{s}=$ The Total Asset Size of research samples.

5) After selecting the matching samples can satisfy the above conditions by step 3 and 4 , the sample with minimum will be chosen as final matching samples. The calculated formula of $\mid$ TOTALCHR $\mid$ is:

$$
\mid \text { TOTALCHR }|=| R O A C H R|+| \text { AssetCHR } \mid
$$

Besides, this paper makes further research of the CSR Report's contribution to CAR though establish Return Model as follow:

$$
C A R_{t}=\beta_{0}+\beta_{1} U E_{t}+\beta_{2} C S R_{t}+\beta_{3} E P S_{t-1}+e_{t}
$$

In the above formula, $C A R_{t}$ represents the cumulative abnormal return of samples within the selected window based on the CSR Report disclosure day; $U E_{t}$ represents unexpected earning of samples; $C S R_{t}$ represents whether samples disclosed CSR Report as a dummy variable; $E P S_{t-1}$ represents earnings per share of samples last year. If $\beta_{2}>0$ significantly, it means that CSR Report has significant market effect; otherwise, the disclosure of CSR Report has no significant market effect.

\subsubsection{White Book of Chinese CSR Report Disclosure Window}

Whether the market will pay more attention to the companies which disclosed CSR Report and identify the quality of CSR Report, while the disclosure of White Book of Chinese CSR Report. This paper uses the Event Study Method to investigate the market effect of the CSR Report before and after the disclosure of White Book of Chinese CSR Report.

This paper calculates CAR of the trading day interval $(-10,0)$ and $(0,10)$ as 0 represents the disclosure day of White Book of Chinese CSR Report respectively, using independent sample mean T-test and median Z-test, to test market effect of CSR Report disclosed. Samples are divided into 2 groups according to whether the companies disclosed CSR Report or not, and the CAR of each group will be calculated to compare. If the CAR of disclosed samples is greater than the one of undisclosed samples and there are significant differences between them, it means the disclosure of White Book of Chinese CSR Report can reinforce the value of CSR Report.

Meanwhile, depending on the scores on the White Book of Chinese CSR Report, the companies whose score above 30 are clustered into one group and named Started-companies, while companies in another are named Starting-companies as the score is less than or equal to 30; and then the CAR of Started-companies and Starting-companies will be calculated respectively. If the Started-companies' CAR is greater than Starting-companies' CAR and there are significant differences between them, it means that the disclosure of White Book of Chinese CSR Report is helpful for the companies with higher quality CSR Report to catch more attention of the market, videlicet, the market can identify the quality of CSR Report disclosed through the scores of White Book of Chinese CSR Report related.

\section{The Empirical Results and Analysis}

\subsection{Studied Event-The Disclosure of CSR Report}

\subsubsection{Matching Sample Test Results}

Based on the basic matching principles above-mentioned, only 232 research samples have suitable matching samples in the total samples of companies which disclosed CSR Report, and the matching results are shown in 
Table 2. From Table 2, the Mean of research samples and matching samples have no significant differences in Asset Size, Profitability and Performance Growth aspect, and the matching results are satisfactory. Although the Mean of matching samples has significant difference at 0.05 levels in Asset Size aspect, there are no significant differences of the Mean in Profitability and Performance Growth aspect; on the whole, the matching results are relative ideal.

\subsubsection{Cumulative Abnormal Return-CAR Test}

Figure 1 is the Trend Chart of CAR within the event window, including the tendency of research samples and matching samples. From Figure 1, the CAR of both the research samples and matching samples present smooth steady state in the window $(-10,-5)$; the CAR of both rise quickly in the window $(-5,-1)$; when $t=1$, i.e., the day after disclosure day, the CAR of both drop drastically; and then the CAR of both remain stable trend with the values all less than 0. Besides, all matching samples' CAR values are greater than research samples' except the day which 10 trading day before the disclosure day, i.e., $t=-10$. Moreover, this paper conducts matching samples T-test and median Z-test of the CAR of both samples. The results are shown in Table 3.

Results from Table 3 indicate that all matching samples' CAR values are greater than research samples' except the day which 10 trading day before the disclosure day, i.e., $t=-10$. The gap between them is gradually increasing from $t=-9$ to $t=-1$, then gradually decreasing. The T-value and Z-value show that the CAR in the event window $(-10,10)$ of both have no significant differences; there is no evidence that the disclosure of CSR Report has market effect.

\subsubsection{Return Model Test}

This paper chooses Return Model to compute the CAR in the event window $(-10,10)$, performance change, i.e., UE, and last year's EPS. The descriptive statistics are shown in Table 4, which indicates that all CSR Report disclosed samples' CAR values are greater than CSR Report undisclosed samples', videlicet, the companies

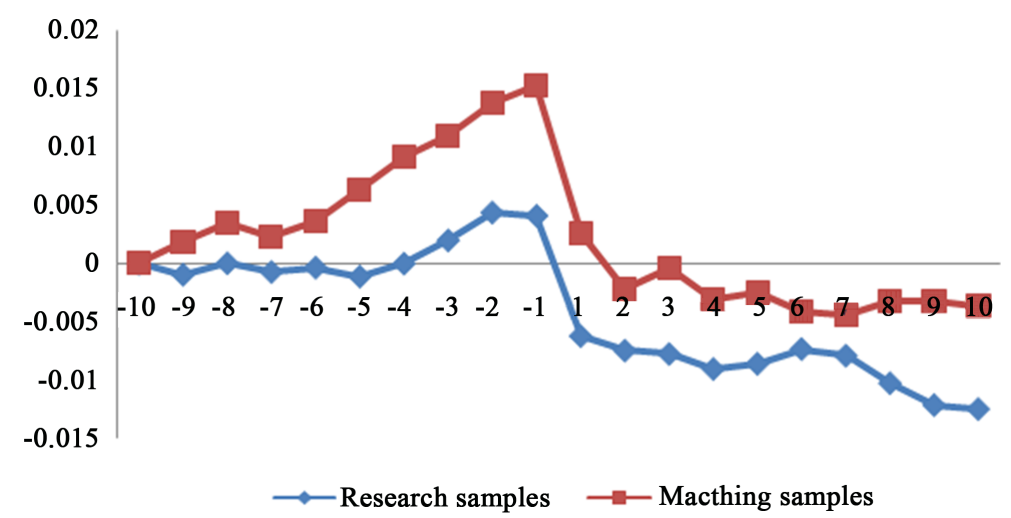

Figure 1. The trend chart of CAR of research samples and matching sample.

Table 2. Matching results of research samples.

\begin{tabular}{ccccc}
\hline Mean & Samples & Research samples & Matching samples & Difference \\
\hline Asset (Billion) & 232 & 57.51 & 57.08 & 0.44 \\
ROA & 232 & 8.74 & 8.74 & 0.00 \\
UE & 232 & 0.0039 & 0.0057 & -0.0018 \\
Median & Samples & Research samples & Matching samples & Difference \\
\hline Asset (Billion) & 232 & 33.78 & 33.90 & -0.12 \\
ROA & 232 & 7.86 & 7.80 & $-2.01^{* *}$ \\
UE & 232 & 0.0035 & 0.0042 & -0.02 \\
\hline
\end{tabular}

Significance levels are indicated by ${ }^{* * *},{ }^{* *},{ }^{*}$ representing $1 \%, 5 \%$, and $10 \%$, respectively. 
Table 3. Matching samples test results.

\begin{tabular}{|c|c|c|c|c|c|}
\hline Event window & Type & Research samples' CAR & Matching samples' CAR & Difference & $\mathrm{T} / \mathrm{Z}$ value \\
\hline \multirow{2}{*}{$(-10,-10)$} & Mean & 0.000011 & -0.000007 & 0.000018 & 0.009988 \\
\hline & Median & -0.001463 & -0.003213 & 0.001751 & -0.523748 \\
\hline \multirow{2}{*}{$(-10,-9)$} & Mean & -0.000918 & 0.001819 & -0.002736 & -0.993454 \\
\hline & Median & -0.004009 & -0.001783 & -0.002226 & -1.679705 \\
\hline \multirow{2}{*}{$(-10,-8)$} & Mean & 0.000064 & 0.003527 & -0.003463 & -0.977376 \\
\hline & Median & -0.005847 & -0.004158 & -0.001689 & -1.055312 \\
\hline \multirow{2}{*}{$(-10,-7)$} & Mean & -0.000691 & 0.002311 & -0.003002 & -0.736007 \\
\hline & Median & -0.002847 & -0.004985 & 0.002138 & -0.586285 \\
\hline \multirow{2}{*}{$(-10,-6)$} & Mean & -0.000322 & 0.003671 & -0.003993 & -0.902009 \\
\hline & Median & -0.003638 & -0.003639 & 0.000000 & -1.033815 \\
\hline \multirow{2}{*}{$(-10,-5)$} & Mean & -0.001084 & 0.006292 & -0.007376 & -1.515793 \\
\hline & Median & -0.003882 & -0.000642 & -0.003240 & -1.445191 \\
\hline \multirow{2}{*}{$(-10,-4)$} & Mean & 0.000024 & 0.009117 & -0.009093 & -1.717454 \\
\hline & Median & -0.000825 & 0.002466 & -0.003291 & -1.492094 \\
\hline \multirow{2}{*}{$(-10,-3)$} & Mean & 0.002008 & 0.010947 & -0.008939 & -1.533352 \\
\hline & Median & -0.002474 & 0.000798 & -0.003272 & -1.127621 \\
\hline \multirow{2}{*}{$(-10,-2)$} & Mean & 0.004398 & 0.013779 & -0.009381 & -1.479156 \\
\hline & Median & -0.003306 & 0.003467 & -0.006773 & -1.071924 \\
\hline \multirow{2}{*}{$(-10,-1)$} & Mean & 0.004127 & 0.015266 & -0.011139 & -1.640481 \\
\hline & Median & -0.001143 & -0.000130 & -0.001013 & -1.173546 \\
\hline \multirow{2}{*}{$(-10,1)$} & Mean & -0.006178 & 0.002529 & -0.008707 & -1.271257 \\
\hline & Median & -0.004219 & -0.000475 & -0.003744 & -0.742627 \\
\hline \multirow{2}{*}{$(-10,2)$} & Mean & -0.007426 & -0.002152 & -0.005275 & -0.737781 \\
\hline & Median & -0.004080 & -0.011095 & 0.007015 & -0.194451 \\
\hline \multirow{2}{*}{$(-10,3)$} & Mean & -0.007715 & -0.000421 & -0.007294 & -1.008820 \\
\hline & Median & -0.008511 & -0.003045 & -0.005466 & -0.567719 \\
\hline \multirow{2}{*}{$(-10,4)$} & Mean & -0.008996 & -0.003036 & -0.005960 & -0.804038 \\
\hline & Median & -0.010351 & -0.007373 & -0.002978 & -0.465119 \\
\hline \multirow{2}{*}{$(-10,5)$} & Mean & -0.008557 & -0.002561 & -0.005996 & -0.782087 \\
\hline & Median & -0.006262 & -0.010302 & 0.004040 & -0.293142 \\
\hline \multirow{2}{*}{$(-10,6)$} & Mean & -0.007291 & -0.004080 & -0.003211 & -0.410251 \\
\hline & Median & -0.008098 & -0.011783 & 0.003684 & -0.120188 \\
\hline \multirow{2}{*}{$(-10,7)$} & Mean & -0.007861 & -0.004441 & -0.003421 & -0.436914 \\
\hline & Median & -0.008309 & -0.011685 & 0.003375 & -0.055697 \\
\hline \multirow{2}{*}{$(-10,8)$} & Mean & -0.010211 & -0.003296 & -0.006915 & -0.847188 \\
\hline & Median & -0.011330 & -0.015071 & 0.003742 & -0.238422 \\
\hline \multirow{2}{*}{$(-10,9)$} & Mean & -0.012086 & -0.003270 & -0.008816 & -1.083808 \\
\hline & Median & -0.015005 & -0.015995 & 0.000989 & -0.509090 \\
\hline \multirow{2}{*}{$(-10,10)$} & Mean & -0.012426 & -0.003626 & -0.008801 & -1.082546 \\
\hline & Median & -0.014734 & -0.013523 & -0.001211 & -0.671296 \\
\hline
\end{tabular}

Significance levels are indicated by ${ }^{* * *},{ }^{* *},{ }^{*}$ representing $1 \%, 5 \%$, and $10 \%$, respectively. 
Table 4. The descriptive statistics of return model.

\begin{tabular}{ccccccc}
\hline Variable & Classification & $\mathrm{N}$ & Minimum & Maximum & Mean & Std \\
\hline \multirow{3}{*}{ CAR } & Total sample & 1857 & -0.2656972 & 0.4076416 & -0.0099473 & 0.0950108 \\
& Disclosed samples & 474 & -0.2119918 & 0.3442839 & -0.0062126 & 0.0871312 \\
& Undisclosed samples & 1383 & -0.2656972 & 0.4076416 & -0.0112273 & 0.0975621 \\
& Total sample & 1857 & -0.2299544 & 0.2172024 & 0.0020907 & 0.0233056 \\
\multirow{2}{*}{ UE } & Disclosed samples & 474 & -0.2299544 & 0.1922689 & 0.0032514 & 0.0265848 \\
& Undisclosed samples & 1383 & -0.1863636 & 0.2172024 & 0.0016928 & 0.0220664 \\
& Total sample & 1857 & -0.1833196 & 0.2022727 & 0.0209933 & 0.0244479 \\
EPS & Disclosed samples & 474 & -0.1166807 & 0.1920523 & 0.0286470 & 0.0278728 \\
& Undisclosed samples & 1383 & -0.1833196 & 0.2022727 & 0.0183702 & 0.0225793 \\
CSR & Total sample & 1857 & 0 & 1 & 0.26 & 0.436 \\
\hline
\end{tabular}

which disclosed CSR Report can get a better market effect. The regression results of Return Model are displayed in Table 5. Results from Table 5 show that, the coefficient of UE is 0.337 , significant at $1 \%$ level; but the coefficients of EPS and CSR are not significant. In other words, the disclosure of CSR Report did not cause significant market effect.

In summary, there is no evidence that the disclosure of CSR Report has significant market effect through Matching sample test and Return Model test. Therefore, assumption 1 couldn't be supported. The possible causes are as follows: China's capital market is an imperfect market with deficiencies like functional fixation or information overload. The market is short of understanding the CSR Report; it can't identify the quality and the information value of CSR Report without the third-party rating agencies. So, will the rating scores of White Book of Chinese CSR Report are helpful for the companies which disclosed CSR Report to get significant market effect?

\subsection{Studied Event-The Disclosure of White Book of Chinese CSR Report 2011}

\subsubsection{Disclosed Samples and Undisclosed Samples}

Figure 2 shows that, in the interval extending from 10 trading day before to 10 trading day after relative to the White Book of Chinese CSR Report disclosure day, all disclosed samples' CAR values are greater than undisclosed samples'; the CAR of both drop gradually from $t=-4$ to $t=10$ with the descending speed of disclosed samples less than the one of undisclosed samples. The result is as expected. This paper conducts matching samples T-test and median Z-test of the CAR of both samples in order to check for significant differences between the two samples. The results are shown in Table 6.

Results from Table 6 indicate that all disclosed samples' CAR values are greater than undisclosed samples' except the four days when $t=-7,-6,1,2$, showing that CSR Report can generate significant market effect and the information value of CSR Report obtains reinforcement while the White Book of Chinese CSR Report is disclosed.

CSR Report Meanwhile, depending on the scores on the White Book of Chinese CSR Report, the companies whose score above 30 are clustered into one group and named Started-companies, while companies in another are named Starting-companies as the score is less than or equal to 30; and then the CAR of Started-companies and Starting-companies will be calculated respectively. If the Started-companies' CAR is greater than Starting-companies' CAR and there are significant differences between them, it means that the disclosure of White Book of Chinese CSR Report is helpful for the companies with higher quality CSR Report to catch more attention of the market, videlicet, the market can identify the quality of CSR Report disclosed through the scores of White Book of Chinese CSR Report related.

\subsubsection{Started Samples and Starting Samples}

According to the scores on the White Book of Chinese CSR Report, grand total of 107 started samples and 384 starting samples are selected. Figure 3 shows that, all started samples' CAR values are greater than starting 
Table 5. The regression results of return model.

\begin{tabular}{cc}
\hline UE & $0.337(2.781)^{* * *}$ \\
CSR & $0.003(0.623)$ \\
EPS & $0.120(1.021)$ \\
Intercept & -0.014 \\
$\mathrm{~N}$ & 1857 \\
Adj.R2 & 0.005 \\
\hline
\end{tabular}

For the companies which disclosed CSR Report, $C A R_{t}$ represents the Cumulative Abnormal Return of the time-interval which extends from trading day -10 to trading day +10 relative to the disclosure day of CSR Report; Meanwhile, other samples' $C A R_{t}$ represents the Cumulative Abnormal Return of the time-interval which extends from trading day -10 to trading day +10 relative to the disclosure day of Annual Financial Statements. Significance levels are indicated by ${ }^{* * * *},{ }^{* * *},{ }^{*}$ representing $1 \%, 5 \%$, and $10 \%$, respectively.

Table 6. Disclosed samples and undisclosed samples test results.

\begin{tabular}{|c|c|c|c|c|c|}
\hline Event window & Type & Disclosed samples’ CAR & Undisclosed samples’ CAR & Difference & $\mathrm{T} / \mathrm{Z}$ value \\
\hline \multirow{2}{*}{$(-10,-10)$} & Mean & -0.014918 & -0.022559 & 0.007640 & $7.183458^{* * *}$ \\
\hline & Median & -0.013994 & -0.022035 & 0.008041 & $-7.084978^{* * *}$ \\
\hline \multirow{2}{*}{$(-10,-9)$} & Mean & -0.011567 & -0.015936 & 0.004369 & $3.284896^{* * *}$ \\
\hline & Median & -0.009498 & -0.014181 & 0.004683 & $-3.545028^{* * *}$ \\
\hline \multirow{2}{*}{$(-10,-8)$} & Mean & -0.011473 & -0.015003 & 0.003530 & $2.343842^{* *}$ \\
\hline & Median & -0.008787 & -0.014124 & 0.005337 & $-2.852598^{* * *}$ \\
\hline \multirow{2}{*}{$(-10,-7)$} & Mean & -0.010325 & -0.011875 & 0.001550 & 0.903846 \\
\hline & Median & -0.007763 & -0.011909 & 0.004147 & -1.309294 \\
\hline \multirow{2}{*}{$(-10,-6)$} & Mean & -0.013135 & -0.015725 & 0.002590 & 1.281664 \\
\hline & Median & -0.011200 & -0.014853 & 0.003653 & -1.590775 \\
\hline \multirow{2}{*}{$(-10,-5)$} & Mean & -0.014363 & -0.018503 & 0.004140 & $1.885935^{*}$ \\
\hline & Median & -0.009887 & -0.016144 & 0.006256 & $-1.974774^{* *}$ \\
\hline \multirow{2}{*}{$(-10,-4)$} & Mean & -0.028509 & -0.037347 & 0.008838 & $3.240453^{* * *}$ \\
\hline & Median & -0.026023 & -0.037962 & 0.011939 & $-3.929731^{* * *}$ \\
\hline \multirow{2}{*}{$(-10,-3)$} & Mean & -0.036023 & -0.047931 & 0.011908 & $3.868711^{* * *}$ \\
\hline & Median & -0.031223 & -0.046195 & 0.014973 & $-4.401451^{* * *}$ \\
\hline \multirow{2}{*}{$(-10,-2)$} & Mean & -0.041764 & -0.052511 & 0.010747 & $2.829638^{* * * *}$ \\
\hline & Median & -0.037024 & -0.049280 & 0.012256 & $-3.069522^{* * *}$ \\
\hline \multirow{2}{*}{$(-10,-1)$} & Mean & -0.033846 & -0.042275 & 0.008429 & $2.288374^{* *}$ \\
\hline & Median & -0.033838 & -0.042328 & 0.008490 & $-2.681296^{* * *}$ \\
\hline \multirow{2}{*}{$(-10,1)$} & Mean & -0.030563 & -0.035335 & 0.004772 & 1.174551 \\
\hline & Median & -0.030963 & -0.035624 & 0.004661 & -1.623451 \\
\hline \multirow{2}{*}{$(-10,2)$} & Mean & -0.032791 & -0.038863 & 0.006072 & 1.497010 \\
\hline & Median & -0.031812 & -0.038453 & 0.006641 & $-1.831567^{*}$ \\
\hline
\end{tabular}




\begin{tabular}{|c|c|c|c|c|c|}
\hline \multicolumn{6}{|l|}{ Continued } \\
\hline \multirow{2}{*}{$(-10,3)$} & Mean & -0.043681 & -0.054446 & 0.010765 & $2.459660^{* *}$ \\
\hline & Median & -0.040344 & -0.053885 & 0.013541 & $-2.773508^{* * *}$ \\
\hline \multirow{2}{*}{$(-10,4)$} & Mean & -0.050979 & -0.071024 & 0.020045 & $4.047978^{* * *}$ \\
\hline & Median & -0.050264 & -0.073936 & 0.023673 & $-4.437120^{* * *}$ \\
\hline \multirow{2}{*}{$(-10,5)$} & Mean & -0.048723 & -0.071478 & 0.022755 & $4.593626^{* * *}$ \\
\hline & Median & -0.048174 & -0.073376 & 0.025202 & $-4.996736^{* * *}$ \\
\hline \multirow{2}{*}{$(-10,6)$} & Mean & -0.048238 & -0.072422 & 0.024184 & $4.895921^{* * * *}$ \\
\hline & Median & -0.045416 & -0.074251 & 0.028835 & $-5.117925^{* * *}$ \\
\hline \multirow{2}{*}{$(-10,7)$} & Mean & -0.061488 & -0.093799 & 0.032312 & $6.334866^{* * *}$ \\
\hline & Median & -0.056973 & -0.093283 & 0.036310 & $-6.545853^{* * *}$ \\
\hline \multirow{2}{*}{$(-10,8)$} & Mean & -0.066431 & -0.104058 & 0.037626 & $7.213373^{* * *}$ \\
\hline & Median & -0.059881 & -0.104657 & 0.044775 & $-7.620609^{* * *}$ \\
\hline \multirow{2}{*}{$(-10,9)$} & Mean & -0.067309 & -0.105325 & 0.038016 & $7.200067^{* * *}$ \\
\hline & Median & -0.063530 & -0.106396 & 0.042866 & $-7.507523^{* * *}$ \\
\hline \multirow{2}{*}{$(-10,10)$} & Mean & -0.062394 & -0.098913 & 0.036520 & $6.971140^{* * *}$ \\
\hline & Median & -0.060019 & -0.100414 & 0.040395 & $-7.235289^{* * *}$ \\
\hline
\end{tabular}

Significance levels are indicated by ${ }^{* * *},{ }^{* *},{ }^{*}$ representing $1 \%, 5 \%$, and $10 \%$, respectively.

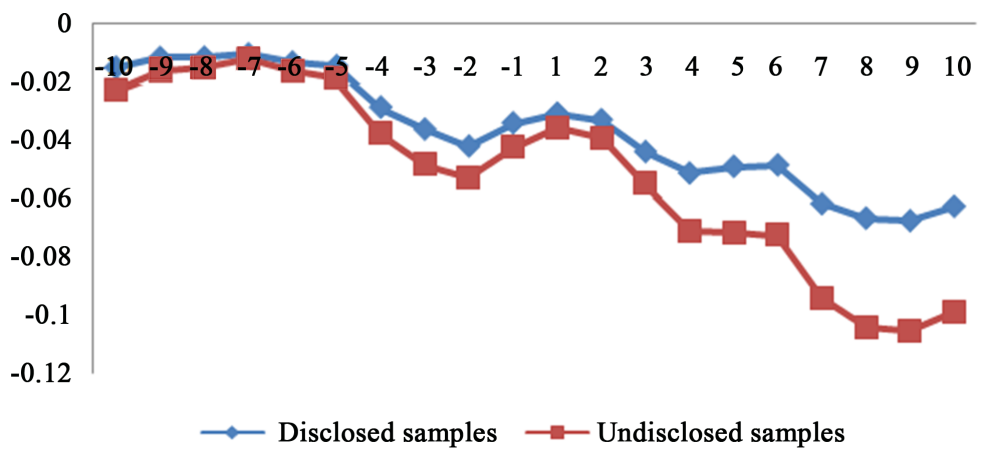

Figure 2. The trend chart of CAR of disclosed samples and undisclosed samples.

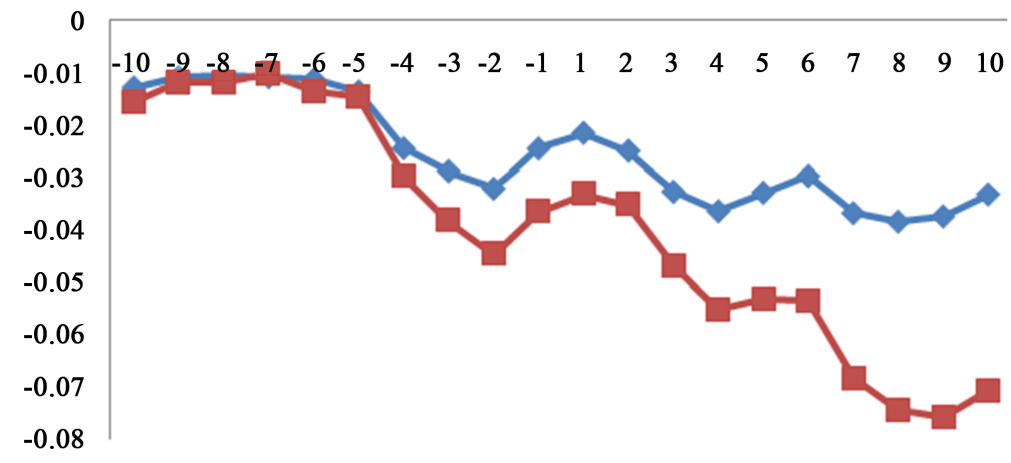

$\multimap$ Starte samples $\rightarrow$ Starting samples

Figure 3. The trend chart of CAR of started samples and starting samples. 
samples' CAR except the day when $t=-7$; the CAR of both drop gradually from $t=-4$ with the gap between them increasing gradually. This means that the higher the quality of CSR Report disclosed, the more significant the market effect. Besides, the results of T-test and median Z-test for started samples and starting samples are shown in Table 7.

Results from Table 7 indicate that all started samples’ CAR values are greater than starting samples' CAR. Moreover, there are significant differences between them from $t=4$ to $t=10$. All of these show that the disclosure of White Book of Chinese CSR Report is helpful for the companies with higher quality CSR Report to catch more attention of the market; the market can identify the quality of CSR Report disclosed through the scores of White Book of Chinese CSR Report related. Therefore, higher rating score means higher quality of CSR Report, means the more significant market effect.

The above-mentioned results provide supporting evidence for assumption 2 and assumption 3 . Along with the disclosure of White Book of Chinese CSR Report, the market will pay attention to corporate social responsibility. CSR Report is the information carrier of the fulfillment of social responsibility, which can convey the information of companies in all aspects such as corporate strategy, environmental protection work and treatment of employees. The disclosure of CSR Report can embody the positivity of the fulfillment of social responsibility and sustainable development capacity; it is benefit to improve social image and reputation. As a consequence, White Book of Chinese CSR Report could reinforce the market's response to CSR Report disclosed by companies. Moreover, the rating scores in White Book of Chinese CSR Report could help the market strengthen the cognition of CSR Report and identify the companies having higher quality of CSR Report. In short, the White Book of Chinese CSR Report delivers authoritative reliable CSR rating information to the market and reinforces market effect on the information of CSR Report.

\section{Robustness Test}

To ensure the reliability of test results, this paper chooses different window length to re-test. The different window extends from trading day -15 to trading day +15 relative to the event-day, for a total of 30 . The re-test results are consistent with the test results of window $(-10,10)$.

For another, this paper tests the existence of market effect on the disclosure of CSR Report further, from the point of the percentage of shares owned by institutional investors in the sample firms (IVPER). Compared with individual investors, institutional investors are generally professional. Institutional investors have the specialized ability to evaluate corporation value, to guide market running efficaciously, and to reduce the information asymmetry. Institutional investors could identify the information transmitted by companies which disclosed CSR Report, then to buy stocks or increase its holdings. This paper obtains 1792 companies with institutional investors from 1857 samples, 64 of which are excluded for disqualification. Next, IVPER are put into two groups depending on the Mean, the market effects on the CSR Report disclosed by companies of High IVPER sample and Low IVPER samples will be tested respectively. The results are shown in Table 8.

Results from Table 8 show that, there is no evidence that the market effect on CSR Report will be different if the companies are differentiated between High IVPER and Low IVPER. The empirical results of this paper have been strengthened.

\section{Conclusion and Discussion}

Using data of Chinese listed companies in A-share market, this paper investigates the market effect of the disclosure of CSR Report and tests the degree of attention the market pays to the quality of CSR Report disclosed. Results of the study show that the information in CSR Report has no significant market effect as the disclosure of CSR Report. However, when the White Book of Chinese CSR Report is released, the information in CSR Report can generate significant market effect. Moreover, the higher the quality of CSR Report disclosed, the more significant the market effect. In conclusion, the White Book of Chinese CSR Report has a reinforcing action on the information in CSR Report. As most of the companies disclose CSR Report and Annual Financial Report at the same time, the possible problem of functional fixation and information overload in the market may lead to the information of CSR Report lacks of adequate attention of the market. The White Book of Chinese CSR Report rating information released by the social responsibility research center of Chinese Academy of Sciences, providing the market with independent and reliable assessment information, can improve the cognitive ability of the market to identify the quality of CSR Report disclosed. 
Table 7. Started samples and starting samples test results.

\begin{tabular}{|c|c|c|c|c|c|}
\hline Event window & Type & Started samples' CAR & Starting samples' CAR & Difference & $\mathrm{T} / \mathrm{Z}$ value \\
\hline \multirow{2}{*}{$(-10,-10)$} & Mean & -0.012993 & -0.015455 & 0.002462 & 1.176867 \\
\hline & Median & -0.011557 & -0.014500 & 0.002943 & $-1.901134^{*}$ \\
\hline \multirow{2}{*}{$(-10,-9)$} & Mean & -0.010993 & -0.011727 & 0.000734 & 0.280165 \\
\hline & Median & -0.007466 & -0.010540 & 0.003075 & -0.811681 \\
\hline \multirow{2}{*}{$(-10,-8)$} & Mean & -0.010723 & -0.011682 & 0.000958 & 0.325008 \\
\hline & Median & -0.006021 & -0.010171 & 0.004150 & -0.689562 \\
\hline \multirow{2}{*}{$(-10,-7)$} & Mean & -0.011031 & -0.010128 & -0.000904 & -0.267463 \\
\hline & Median & -0.006764 & -0.008484 & 0.001720 & -0.182599 \\
\hline \multirow{2}{*}{$(-10,-6)$} & Mean & -0.011398 & -0.013619 & 0.002221 & 0.544123 \\
\hline & Median & -0.011099 & -0.011349 & 0.000250 & -0.476915 \\
\hline \multirow{2}{*}{$(-10,-5)$} & Mean & -0.013741 & -0.014537 & 0.000796 & 0.179481 \\
\hline & Median & -0.010405 & -0.009856 & -0.000549 & -0.083980 \\
\hline \multirow{2}{*}{$(-10,-4)$} & Mean & -0.024418 & -0.029649 & 0.005232 & 0.946170 \\
\hline & Median & -0.024158 & -0.026474 & 0.002315 & -0.755052 \\
\hline \multirow{2}{*}{$(-10,-3)$} & Mean & -0.028769 & -0.038045 & 0.009276 & 1.463780 \\
\hline & Median & -0.023673 & -0.034425 & 0.010753 & -1.252769 \\
\hline \multirow{2}{*}{$(-10,-2)$} & Mean & -0.032110 & -0.044454 & 0.012344 & 1.607491 \\
\hline & Median & -0.031089 & -0.039310 & 0.008221 & -1.231196 \\
\hline \multirow{2}{*}{$(-10,-1)$} & Mean & -0.024484 & -0.036455 & 0.011971 & 1.588781 \\
\hline & Median & -0.028512 & -0.036168 & 0.007656 & -1.118709 \\
\hline \multirow{2}{*}{$(-10,1)$} & Mean & -0.021547 & -0.033075 & 0.011528 & 1.387526 \\
\hline & Median & -0.021465 & -0.033134 & 0.011669 & -1.044745 \\
\hline \multirow{2}{*}{$(-10,2)$} & Mean & -0.024902 & -0.034990 & 0.010087 & 1.252200 \\
\hline & Median & -0.025338 & -0.034329 & 0.008990 & -0.933028 \\
\hline \multirow{2}{*}{$(-10,3)$} & Mean & -0.032687 & -0.046745 & 0.014058 & 1.568054 \\
\hline & Median & -0.030597 & -0.044602 & 0.014005 & -1.294374 \\
\hline \multirow{2}{*}{$(-10,4)$} & Mean & -0.036363 & -0.055051 & 0.018688 & $1.882797^{*}$ \\
\hline & Median & -0.037055 & -0.056930 & 0.019875 & $-1.762814^{*}$ \\
\hline \multirow{2}{*}{$(-10,5)$} & Mean & -0.032847 & -0.053147 & 0.020300 & $2.016705^{* *}$ \\
\hline & Median & -0.033716 & -0.053060 & 0.019344 & $-1.974691^{* *}$ \\
\hline \multirow{2}{*}{$(-10,6)$} & Mean & -0.029707 & -0.053402 & 0.023695 & $2.325657^{* *}$ \\
\hline & Median & -0.027398 & -0.051053 & 0.023655 & $-2.269007^{* *}$ \\
\hline \multirow{2}{*}{$(-10,7)$} & Mean & -0.036747 & -0.068381 & 0.031634 & $2.945582^{* * *}$ \\
\hline & Median & -0.028449 & -0.063697 & 0.035248 & $-2.995552^{* * *}$ \\
\hline \multirow{2}{*}{$(-10,8)$} & Mean & -0.038361 & -0.074253 & 0.035892 & $3.287765^{* * *}$ \\
\hline & Median & -0.031282 & -0.069835 & 0.038553 & $-3.497122^{* * *}$ \\
\hline \multirow{2}{*}{$(-10,9)$} & Mean & -0.037385 & -0.075647 & 0.038262 & $3.492196^{* * *}$ \\
\hline & Median & -0.034360 & -0.068510 & 0.034150 & $-3.667394^{* * *}$ \\
\hline \multirow{2}{*}{$(-10,10)$} & Mean & -0.033179 & -0.070534 & 0.037355 & $3.442925^{* * *}$ \\
\hline & Median & -0.033991 & -0.067601 & 0.033610 & $-3.557218^{* * *}$ \\
\hline
\end{tabular}

Significance levels are indicated by ${ }^{* * *},{ }^{* *},{ }^{*}$ representing $1 \%, 5 \%$, and $10 \%$, respectively. 
Table 8. Return model results of IVPER.

\begin{tabular}{ccc}
\hline Variable & High IVPER & Low IVPER \\
\hline UE & $0.422(2.663)^{* * * *}$ & $0.263(1.353)$ \\
CSR & $-0.010(-1.453)$ & $0.012(1.473)$ \\
EPS & $0.222(1.479)$ & $0.20(0.103)$ \\
Intercept & -0.008 & -0.013 \\
N & 898 & 894 \\
Adj.R2 & 0.009 & 0.006 \\
\hline
\end{tabular}

Significance levels are indicated by ${ }^{* * *},{ }^{* *},{ }^{*}$ representing $1 \%, 5 \%$, and $10 \%$, respectively.

The theoretical analysis and empirical data in this paper have the following policy implications. Firstly, this paper finds that the disclosure of CSR Report hasn't achieved the expected market effect in practice until the release of White Book of Chinese CSR Report. The possible problem of functional fixation and information overload in the market may lead to the information of CSR Report lacks of adequate attention of the market. Therefore, the CSRC can consider staggering the disclosure time of CSR Report and Annual Financial Report, further standardizing the quality of CSR Report disclosed. Secondly, this paper finds that the White Book of Chinese CSR Report can reinforce the market effect on CSR Report, which means that the non-financial information disclosure of listed companies in China should be integrated into more third-party supervision, in order to promote the development of non-financial information disclosure. Thirdly, the CSR Report disclosure of listed companies in China is its infancy stage, lacking of specific standards and supervision. Therefore, our government and department concerned should formulate specific standards to quantify the quality of CSR Report disclosure, along with consummating series of processes such as standards establishing, assessment and supervision constantly.

\section{References}

[1] Ingram, R.W. (1978) An Investigation of the Information Content of Social Responsibility Disclosures. Journal of Accounting Research, 16, 270-285. http://dx.doi.org/10.2307/2490567

[2] Margolis, J. and Walsh, J. (2003) Misery Loves Companies: Rethinking Social Initiatives by Business. Administrative Science Quarterly, 48, 268-305. http://dx.doi.org/10.2307/3556659

[3] McWilliams, A., Siegel, D.S. and Wright, P.M. (2006) Corporate Social Responsibility: Strategic Implications. Journal of Management Studies, 43, 1-18. http://dx.doi.org/10.1111/j.1467-6486.2006.00580.X

[4] Waddock, S. and Graves, S. (1997) The Corporate Social Performance-Financial performance Link. Strategic Management Journal, 18, 303-319.

http://dx.doi.org/10.1002/(SICI)1097-0266(199704)18:4<303::AID-SMJ869>3.0.CO;2-G

[5] Hillman, A. and Keim, G. (2001) Shareholder Value, Stakeholder Management, and Social Issues: What's the Bottom Line? Strategic Management Journal, 22,125-139. http://dx.doi.org/10.1002/1097-0266(200101)22:2<125::AID-SMJ150>3.0.CO;2-H

[6] Verschoor, C. and Murphy, E. (2002) The Financial Performance of Large US Firms and Those with Global Prominence: How Do the Best Corporate Citizens Rate? Business and Society Review, 107, 371-380. http://dx.doi.org/10.1111/1467-8594.00141

[7] Hull, C.E. and Rothenberg, S. (2008) Firm Performance: The Interactions of Corporate Social Performance with Innovation and Industry Differentiation. Strategic Management Journal, 29, 781-789. http://dx.doi.org/10.1002/smj.675

[8] Anderson, J. and Frankle, A. (1980) Voluntary Social Reporting: An Iso-Beta Portfolio Analysis. The Accounting Review, 7, 467-479.

[9] Hill, R.P., Ainscough, T., Shank, T. and Manullang, D. (2007) Corporate Social Responsibility and Socially Responsible Investing: A Global Perspective. Journal of Business Ethics, 70, 165-174. http://dx.doi.org/10.1007/s10551-006-9103-8

[10] Cheung, Y.L., Tan, W., Ahn, H.J. and Zhang, Z. (2010) Does Corporate Social Responsibility Matter in Asian Emerging Markets? Journal of Business Ethics, 92, 401-413. http://dx.doi.org/10.1007/s10551-009-0164-3 
[11] Cheung, Y., Jiang, K. and Tan, W. (2012) "Doing-Good” and “Doing-Well” in Chinese Publicly Listed Firms. China Economic Review, 23, 776-785. http://dx.doi.org/10.1016/j.chieco.2012.03.013

[12] Chen, Y.-Q. and Ma, L.-L. (2005) Empirical Analysis on Market Reaction of the Corporate Social Responsibility Information. Journal of Accounting Research, 11, 76-81.

[13] Wen, S.-B. and Fang, W. (2008) The Empirical Study on Relationship between Corporate Social Responsibility and Financial Performance-Panel Data Analysis of Stakeholder Perspective. Chinese Industrial Economy, 10, 150-160.

[14] Li, Z. (2006) Empirical Research on Correlation between Corporate Social Responsibility and Corporate Value-From Shanghai Stock Market Listed Companies. Chinese Industrial Economy, 2, 77-83.

[15] Song, X.-Z. and Gong, M.-X. (2007) The Quality and Decision Value Evaluation of the Social Responsibility- Analysis of the Accounting Reports of Listed Companies. Journal of Accounting Research, 2, 37-43.

[16] Shen, H.-T. and Yang, Y. (2008) Research on Correlation between Corporate Social Responsibility and Corporate Value-The Empirical Evidence from Chinese Listed Companies. Contemporary Finance \& Economics, 3, 150-160.

[17] Zhu, S. (2011) Corporate Social Responsibility, Market Assessment and the Earnings Information Content. Journal of Accounting Research, 11, 27-34.

[18] Jiang, Y.-J., Xu, Y., Liu, D.-G. and Zhou, M.-H. (2011) Market Effect on Corporate Social Responsibility Information-Based on the Event Study of Disclosure of Chinese Listed Companies' Social Responsibility Report. Research on Economics and Management, 8, 123-128.

[19] Zhai, H.-Y. (2012) Research on the Influence of the Quality of Corporate Social Responsibility Disclosed on Investors Trade Behavior-Based on the Empirical Analysis of Listed Companies in China. Economic Survey, 1, 82-86.

[20] Shen, H.-T. and Feng, J. (2012) Public Opinion, Government Regulation and Corporate Environmental Information Disclosure. Journal of Accounting Research, 2, 72-78.

[21] Gross, A. and Roberts, S. (2011) The Impact of Corporate Social Responsibility on the Cost of Bank Loans. Journal of Banking and Finance, 35, 1794-1810. http://dx.doi.org/10.1016/j.jbankfin.2010.12.002

[22] Huang, Y.-X. and Li, Y.-H. (2012) The Influence of Social Responsibility Information and Financial Performance on Bank Loan Decision-Making-Based on the Perspective of Bank Loan Financing Costs. Friends of Accounting, 21, 29-32. 